До історико-культурної спадщини Туреччини належать: 1) Трипільська культура; 2) Парфенон; 3) руїни Трої.

Серед віруючих у Франції переважають: 1) протестанти; 2) римо-католики; 3) православні; 4) буддисти.

Коротко схарактеризуйте Трипільську культуру.

Охарактеризуйте історико-культурну спадщину Японії.

Розроблення країнознавчого складника у змісті географічної компетентності учнів основної школи у процесі вивчення географії України уможливлює: формування системи географічних i країнознавчих знань у їх взаємозв'язках; розмежування географічного і країнознавчого образів; реалізацію принципів послідовності й наступності. Вивчення образів у тісному взаємозв'язку сприяє у старшій школі формуванню країнознавчої компетентності під час вивчення економічної і соціальної географії.

Перспективою подальших досліджень визначаємо з'ясування змісту і структури інформаційного (категорійно-поняттєвого) складника географічної компетентності учнів основної школи у процесі вивчення географії України.

1. Скавронський П. Зміст i структура поняття «картознавча компетенція» /Павло Скавронський // Географія та основи економіки в школі. - 2009. № 6. - С. 32-37. 2. Яценко В. Формування й оцінювання ключових компетентностей учня на заняттях географії / В. Яценко // Післядипломна освіта в Україні. - 2007. № 2. - C. 79-82.

УДК 373.5.016:811.161.2

Любов Цоуфал

\title{
КОМУНІКАТИВНА КОМПЕТЕНЦІЯ УЧНІВ У КОНТЕКСТІ СУЧАСНИХ ПРОБЛЕМ НАВЧАННЯ УКРАЇНСЬКОЇ МОВИ
}

Цоуфал Л. С. Комунікативна компетенція учнів у контексті сучасних проблем навчання української мови.

У статті розкрито сутність поняття «комунікативна компетенція», розглянуто структуру і схарактеризовано основні складники означеного поняття, визначено педагогічні умови формування комунікативної компетенції учнів у процесі навчання української мови.

Ключові слова: комунікативна компетенція, структура комунікативної компетенції, мовленнєвий розвиток учнів, навчання української мови.

Цоуфал Л. С. Коммуникативная компетенция учащихся в контексте современных проблем обучения украинскому языку.

В статье раскрыта суть понятия «коммуникативная компетенция», рассмотрена структура и охарактеризованы основные составляющие названого понятия, выделены педагогические условия формирования коммуникативной компетенции учащихся в процессе обучения украинскому языку.

Ключевые слова: коммуникативная компетенция, структура коммуникативной компетенции, речевое развитие учащихся, обучение украинскому языку.

Tsoufal L. S. Communicative competence of students in the context of contemporary issues of teaching Ukrainian.

The article deals with the definition «communicative competence», examines the structure and characterizes basic components of the forementioned concept, highlights pedagogical conditions of communicative competence formation in the process of Ukrainian language learning.

Key words: communicative competence, structure of communicative competence, students' language development, Ukrainian language teaching. 
В умовах реформування мовної освіти оновлення змісту, структури, методів, організаційних форм навчання української мови спрямоване на створення оптимальних умов для піднесення ефективності навчально-виховного процесу, реалізації особистісного потенціалу кожного учня.

Предметні цілі сучасного курсу української мови максимально наближені до життєвих потреб учнів, відображають їхні життєві орієнтири, спрямовують курс на інтенсивний мовленнєвий, інтелектуальний і духовний розвиток школярів. При цьому розвиток мовленнєвої діяльності учня розглядається як інтегрований показник його особистісного зростання.

Провідними в навчанні мови на сучасному етапі є особистісно зорієнтований, соціокультурний, комунікативно-діяльнісний, компетентнісний підходи, які, реалізуючись у чинних програмах і відіграючи важливу роль в інтеграції до європейського освітнього простору, орієнтують педагогів на формування ключових компетенцій учнів. Загальноєвропейські рекомендації з мовної освіти визначають два види компетенцій: загальні (знання про світ, національну й загальнолюдську культуру, здатність до навчання, індивідуальний життєвий досвід) і комунікативні мовні, що складаються з трьох компонентів - лінгвістичного, соціолінгвістичного та прагматичного [4]. Проблема формування комунікативної компетенції стає пріоритетною, оскільки успішна участь особистості в суспільних процесах, реалізація планів у професійній галузі,задоволення власних практичних потреб значною мірою залежать від здатності до ефективної комунікації.

До розв'язання окресленої проблеми зверталися дидакти, лінгводидакти, психологи. Питанням формування комунікативної компетенції учнів приділено увагу в дослідженнях багатьох науковців (Ф. Бацевич, О. Бистрова, М. Вятютнєв, М. Вашуленко, О. Глазова, О. Горошкіна, Т. Донченко, С. Срмоленко, М. Жинкін, I. Зимня, С. Караман, Т. Ладиженська, О. Леонтьєв, Г. Лещенко, С Омельчук, М. Пентилюк, Н. Подлевська, А. Хуторський, Г. Шелехова, А. Ярмолюк та ін.).

Mema cmammi - розкрити сутність поняття «комунікативна компетенція», розглянути структуру і схарактеризувати складники означеного поняття.

А. Хуторський, досліджуючи особистісно зорієнтовано освітню парадигму, запропонував трирівневу ієрархію освітніх компетенцій: ключові - належать до загального змісту освіти; загальнопредметні - належать до певних навчальних предметів й освітніх галузей; предметні - мають конкретний опис і можливість формування в межах навчальних предметів. До ключових компетенцій науковець відносить ціннісно-смислову компетенцію, загальнокультурну компетенцію, навчально-пізнавальну компетенцію, інформаційну компетенцію, комунікативну компетенцію, соціально-трудову компетенцію, компетенцію особистісного самовдосконалення [8, с. 63-64]. Відтак, комунікативну компетенцію науковцем віднесено до ключових, що свідчить про необхідність постійної уваги педагогів до формування означеної якості особистості, однак уважаємо за необхідне акцентувати на тому, що мовленнєвий розвиток учнів $є$ першочерговим завданням учителівфілологів. Саме комунікативна компетенція $\epsilon$ показником рівня оволодіння мовою відповідно до вимог чинних програм, основною метою мовної освіти в середній школі, а засобом іiі досягнення - мовленнєва діяльність.

Аналіз педагогічної, лінгвістичної, лінгводидактичної літератури дозволяє стверджувати про наявність різних позицій науковців щодо розкриття сутності поняття«комунікативна компетенція». Акцентуючи на необхідності розмежування компетенції і компетентності, А. Хуторський зазначає, що компетенція - це наперед задана соціальна вимога (норма) до освітньої підготовки учнів, необхідної для якісної продуктивної діяльності в певній галузі, а компетентність - володіння певною компетенцією, що охоплює особистісне ставлення до неї і до предмета діяльності [9, 
с. 106]. Відтак, комунікативну компетенцію доцільно розглядати як вимогу до мовної підготовки школярів, яка дозволить їм ефективно здійснювати комунікативну діяльність.

Комунікативну компетенцію науковці розуміють як здатність користуватися мовою залежно від ситуації, особлива якість мовленнєвої особистості, набута у процесі спілкування або спеціально організованого навчання $[7$, с. 70$]$, як сукупність знань про спілкування, умінь і навичок, потрібних для здійснення мовленнєвої діяльності [5, с. 3-4], як здатність адекватно використовувати мову в різноманітних ситуаціях спілкування, співвідносити мовні засоби з цілями й умовами спілкування, розуміти стосунки між комунікантами, будувати мовленнєве спілкування 3 урахуванням соціальних норм поведінки та системи культурних уявлень і цінностей певної мови [3, с. 18], як не вроджену здатність, а сформовану на основі взаємодії мовця із соціальним середовищем у процесі набуття ним соціально-комунікативного досвіду, це знання, уміння і навички, необхідні для розуміння чужих і породження власних програм мовленнєвої поведінки, адекватних цілям, сферам i ситуаціям спілкування [6, с. 17].

Визначаючи структуру комунікативної компетенції, лінгводидакти виокремлюють такі компоненти:мовленнєва компетенція (уміння застосовувати знання мови на практиці, користуватися мовними одиницями), мовна компетенція (знання одиниць мови та правил їх поєднання),предметна компетенція (уміння на основі активного володіння загальною лексикою відтворювати в свідомості картини світу), прагматична компетенція (здатність до здійснення мовленнєвої діяльності, зумовленої комунікативною метою, до вибору необхідних форм, типів мовлення, урахування функціонально-стильових різновидів мовлення) [7, с. 70].

Лінгвісти найважливішими складниками комунікативної компетенції вважають: мовну компетенцію (здатність розуміти і продукувати необмежену кількість правильних повідомлень); дискурсивну компетенцію (здатність поєднувати повідомлення у зв'язні дискурси); соціолінгвістичну компетенцію (здатність розуміти і продукувати мовлення у конкретному соціолінгвістичному контексті спілкування); стратегічну компетенцію (уміння брати ефективну участь у спілкуванні, добираючи правильну стратегію і тактику спілкування); іллокутивну компетенцію (здатність реалізовувати комунікативні наміри, використовуючи структуру повідомлення (мовленнєвого акту)); соціокультурну компетенцію (уміння використовувати соціокультурний контекст: звичаї, норми, ритуали, соціальні стереотипи) [1, с. 125-126]. Усі компоненти комунікативної компетенції взаємопов'язані, проте найтісніший зв'язок наявний між мовною і мовленнєвою. Мовна компетенція, відбиваючи володіння учнями нормативними лінгвістичними знаннями на теоретичному i практичному рівнях, слугує основою формування мовленнєвої компетенції. Мовленнєві вміння і навички виробляються поступово, відповідно до засвоєння мовної системи, оволодіння нормами літературної мови.

Формування комунікативної компетенції - це складний процес, оскільки поєднує розвиток особистісних лінгвістичних здібностей учнів, формування мовних, мовленнєвих, комунікативних знань, умінь i навичок 3 урахуванням ситуації спілкування. Для того щоб користуватися мовою як засобом спілкування ефективно, необхідно знати соціальні, ситуативні, контекстуальні правила, яких дотримуються носії мови. Що, де, коли, як говорять люди, що спілкуються українською мовою, якого значення надають окремим словам і виразам залежно від різних обставин, регулюється комунікативною компетенцією. Тому М. Вятютнєв визначив іiї як вибір і реалізацію програм мовленнєвої поведінки залежно від здібностей людини орієнтуватися в тих чи тих ситуаціях спілкування, уміння класифікувати ситуації відповідно до теми, завдань, комунікативних намірів, що виникають в учнів до бесіди, 
а також під час бесіди у процесі взаємодії [2, с. 38]. Науковець висловив важливу для нашого дослідження думку про те, що немає двох людей 3 однаковим рівнем комунікативної компетенції, оскільки неоднакова їхня суспільно-комунікативна діяльність. «Починаючи з елементарної компетенції в ранньому дитинстві, людина у своєму розвитку проходить через низку проміжних компетенцій, і вже в зрілому віці в неї утворюється постійна компетенція носія мови, що вирізняється своїми індивідуальними особливостями. Відмінності між людьми, пов'язаними сферою діяльності, полягають у тому, що одні й ті ж комунікативні цілі можуть бути реалізовані з різним ступенем мовленнєвої творчості» [2, с. 39].

Комунікативна компетенція є складним, системним утворенням. Ефективність спілкування залежить не лише від знання мови на всіх іiі рівнях, володіння правилами використання мовних засобів відповідно до сучасних норм у різних ситуаціях, але й від уміння здійснювати вплив на співрозмовника, адекватно декодувати висловлену ним інформацію. Формувати комунікативну компетенцію під час навчання мови в школі - це означає: 1) розвивати вміння розуміти не лише зміст, а й суть усних і письмових текстів; 2) вчити створювати повноцінні в комунікативному відношенні висловлювання, які відображають і знання того, хто говорить (пише) про предмет мовлення, і його думки, почуття, наміри; 3) виявляти вміння налагоджувати взаємодію з оточуючими, відповідним чином будуючи свої висловлювання [10, с. 2]. У методиці навчання української мови формування комунікативної компетенції передбачає засвоєння учнями основних понять лінгвістики мовлення, зокрема стилів, типів мовлення, особливостей побудови розповіді, опису, міркування, вироблення умінь і навичок аналізу висловлювань на певну тему, редагування писемного тексту.

Отже, формування комунікативної компетенції учнів можливе за умови цілеспрямованого, систематичного оволодіння ними всіма складниками означеного поняття.

Перспективу подальших досліджень убачаємо у з'ясуванні психолінгвістичних засад навчання мовленнєвої діяльності учнів основної школи.

\section{Література}

1. Бацевич Ф. С. Основи комунікативної лінгвістики: [підручник] / Ф. С. Бацевич. К. : ВЦ «Академія», 2004.- 344 с. 2. Вятютнев М. Н. Коммуникативная направленность обучения русскому языку в зарубежных школах / М. Н. Вятютнев // Русский язык за рубежом. - 1977. - № 6. - С. 37-45. 3. Гез Н. И. Формирование коммуникативной компетенции как объект исследований / Н. И. Гез // Иностранные языки в школе. 1985. - № 4. - С. 17-23. 4. Загальноєвропейські Рекомендації 3 мовної освіти: вивчення, викладання, оцінювання / наук. ред. С. Ю. Ніколаєва. - К. : Ленвіт, 2003. 273 с. 5. Омельчук С. Формування мовленнєво-комунікативних умінь у процесі вивчення синтаксису/ Сергій Омельчук // Дивослово. - 2006. - № 9. - С. 2-5. 6. Пентилюк М. Концептуальні засади комунікативної методики навчання української мови / М. Пентилюк, О. Горошкіна, А. Нікітіна // Українська мова і література в школі. -2006. - № 1.- С.15-20. 7. Словник-довідник з української лінгводидактики: [навч. посіб.] / кол. авторів за ред. М. Пентилюк.- К. : Ленвіт, 2003. - 140 с. 8. Хуторской А. Ключевые компетенции как компонент личностноориентированной парадигмы образования / А. Хуторской // Народное образование. 2003. - № 2. - С. 58-64. 9. Хуторской А. В. Образовательные компетенции в дидактике и методиках личностно-ориентированного обучения / А. В. Хуторской // Педагогіка вищої та середньої школи: зб. наук. праць / за ред. В. К. Буряка. - Кривий Ріг : КДПУ, 2004. - Вип. 8. - С. 104-112.10. Ярмолюк А. Удосконалення власного писемного мовлення як умова формування комунікативної компетенції учнів / Алла Ярмолюк // Українська мова і література в школі. - 2010. - № 3. - С. 2-8. 